\title{
PENGARUH KEPEMIMPINAN TRANSFORMASIONAL TERHADAP KINERJA KARYAWAN DENGAN MOTIVASI SEBAGAI VARIABEL INTERVENING
}

\author{
Saruful Anam ${ }^{1}$, Zaim Mukaffi ${ }^{2}$ \\ ${ }^{12}$ Fakultas Ekonomi Universitas Islam Negeri (UIN) Maulana Malik Ibrahim Malang \\ ${ }^{1}$ syarofulanam77@gmail.com
}

\begin{abstract}
ABSTRAK
Tujuan penelitian ini untuk mengetahui seberapa besar pengaruh kepemimpinan transformasional terhadap kinerja karyawan Hayaku melalui motivasi. Penelitian ini menggunakan metode kuantitatif dengan pendekatan deskriptif. Sampel yang digunakan sebanyak 50 responden, dengan teknik pengambilan sampel jenuh. Jenis data yang digunakan berupa data primer kuesioner dan sekunder berupa dokumen. Analisis data yang digunakan ialah model analisis jalur (Path Analysis) dengan alat bantu SPSS versi 16.0. Hasil penelitian ini menunjukan bahwa Kepemimpinan Transformasional (X) berpengaruh terhadap Kinerja Karyawan (Y) dengan nilai 0,489. Motivasi (Z) berpengaruh secara signifikan terhadap Kinerja (Y) dengan nilai 0,637. Serta secara tidak langsung Kepemimpinan Transformasional $(\mathrm{X})$ berpengaruh signifikan terhadap Kinerja Karyawan (Y) melalui Motivasi (Z) dengan nilai signifikasi 0,000 dibawah 0,05. Dapat disimpulkan Kepemimpinan Transformasional berpengaruh positif terhadap Kinerja Karyawan dan akan baik dengan mediasi Motivasi.
\end{abstract}

Kata Kunci: Kepemimpinan Transformasional, Kinerja Karyawan, Motivasi

\begin{abstract}
The purpose of this study was to determine how much the influence of transformational leadership on the performance of Hayaku employees through motivation. This research uses a quantitative method with a descriptive approach. The sample used was 50 respondents, with saturated sampling technique. The type of data used is questionnaire primary and secondary data in the form of documents. Analysis of the data used is the path analysis model (Path Analysis) with SPSS version 16.0. The results of this study indicate that Transformational Leadership $(X)$ influences Employee Performance $(Y)$ with a value of 0.489. Motivation ( $Z$ ) significantly influences performance $(Y)$ with a value of 0.637 and indirectly Transformational Leadership $(X)$ has a significant effect on Employee Performance ( $Y$ ) through Motivation (Z) with a significance value of 0,000 below 0.05. It can be concluded that Transformational Leadership has a positive effect on Employee Performance and will be good with motivation mediation.
\end{abstract}

Keywords: Transformational Leadership, Employee Performance, Motivation

\section{PENDAHULUAN}

Di era saat ini, persaingan berbagai usaha semakin dinamis, salah satunya di bidang produk makanan maupun kuliner. Sejatinya bagi perusahaan yang ingin berkembang dan selalu bertahan harus dapat memberikan para konsumen produk yang memuaskan, dari segi barang maupun jasa yang bermutu baik, harga bersaing, penyerahan lebih cepat, dan pelayanan yang lebih baik dari pada pesaing. Untuk memenuhi kepuasan pelanggan, kualitas pelayanan sangat penting dikelola perusahaan dengan baik. 
Kualitas pelayanan merupakan tingkat keunggulan yang diharapkan, dan pengendalian atas tingkat keunggulan untuk memenuhi keinginan pelanggan. Mansyur, dkk (2014) menyatakan "dalam era globalisasi, isu yang paling banyak dikembangkan adalah isu persaingan global". Makna dari persaingan global tersebut ialah bebas bersaing dalam berusaha. Dalam artian, semua perusahaan akan saling berlomba untuk tetap beroperasi dan berkembang. Menyadari hal tersebut, tampak betapa pentingnya usaha pemahaman akan faktor-faktor yang bisa mengoptimalkan kinerja karyawan, guna mencapai keberhasilan dalam suatu usaha organisasi maupun perusahaan.

Zulkfli (2013), mengungkapkan bahwasanya seorang karyawan yang mempunyai kinerja (hasil kerja atau karya yang dihasilkan) yang berkualitas dan baik dapat menunjang tercapainya tujuan dan sasaran yang telah ditetapkan oleh suatu perusahaan. Aspek sumber daya manusia merupakan salah satu aspek yang penting bagi perusahaan, karena strategi-strategi perusahaan nantinya yang akan mengeksekusi ialah para karyawan ataupun sumber daya manusia perusahaan tersebut. Oleh karena itu, perlu adanya pengoptimalan kinerja karyawan agar dapat memberikan hasil yang baik bagi perusahaan.

Hasil kinerja yang berkualitas tinggi akan di dapatkan apabila operasional didalam perusahaan tersebut berjalan dengan efektif, karena dimana kinerja itu merupakan hubungan dari potensi karyawan. Apabila potensi dimanfaatkan dengan optimal, maka hasilnya kinerjanya pun akan memuaskan bagi perusahaan khususnya dan begitupun sebaliknya. Bagi seorang pemimpin yang efektif tentunya harus tanggap terhadap perubahan yang di alami di dalam perusahaan maupun di lingkungan luar, serta mampu menganalisis kekuatan dan kelemahan sumber daya manusia yang dimiliki oleh perusahaan sehingga mampu memaksimalkan kinerja karyawan dalam perusahaan dan menangani masalah yang di alami dengan cepat dan tepat. Pandji (2009), mengemukakan bahwa kepemimpinan merupakan sebuah keahlian dalam mempengaruhi orang lain baik melalui sebuah komunikasi langsung ataupun melalui perilaku. Upaya seseorang pemimpin dalam upaya mempengaruhi bawahan itu guna mencapai tujuan perusahaan ataupun sasaran perusahaan tertentu. Hal ini menunjukan bahwa kepemimpinan itu melibatkan cara penggunaan pengaruh, baik itu melalui komunikasi langsung ataupun tidak langsung. Dari hal diatas yakni terkait komunikasi dalam upaya mempengaruhi bawahan sebagai salah satu cara gaya kepemimpinan dalam perusahaan, yang nantinya diharapkan dalam ketepatan dan kejelasan mengenai komunikasi tersebut dapat memberikan dampak yang baik bagi kinerja karyawan.

Dari survei awal yang dilakukan peneliti melalui, terdapat beberapa fenomena yang terjadi dalam operasional karyawan Hayaku. Yakni kinerja pegawai selama ini dirasakan belum optimal, hal tersebut dapat dilihat dari masih adanya para pegawai yang meninggalkan pekerjaan pada jam kerja dengan alasan yang tidak dapat di pertanggung jawabkan, selalu dihadapi dengan pegawai yang berkeinginan resign dalam jangka waktu yang belum lama dalam perusahaan, menggunakan atau memainkan smartphone di saat jam kerja, dan oknum pegawai yang kurang disiplin dalam hal masuk jam kerja atau terlambat dalam masuk kerja. (Hasil survei ini dari wawancara terhadap Bapak Hendra selaku manajer di Hayaku). Dari hal ini, peneliti tertarik untuk melakukan penelitian terkait pengaruh gaya kepemimpinan terhadap kinerja karyawan serta motivasi sebagai variabel intervalnya. 


\section{Hipotesis}

Berdasarkan teori dan kerangka konseptual tersebut di atas, hipotesis yang akan di lakukan sementara diduga dalam penelitian ini adalah sebagai berikut:

H1: Kepemimpinan transformasional berpengaruh terhadap kinerja karyawan Hayaku.

$\mathrm{H} 2$ : Motivasi berpengaruh positif terhadap kinerja karyawan Hayaku.

H3: Kepemimpinan transformasional berpengaruh positif terhadap motivasi kerja Hayaku

H4: Kepemimpinan transformasional berpengaruh terhadap kinerja karyawan Hayaku dengan motivasi sebagai variabel intervening.

\section{METODE PENELITIAN}

Jenis penelitian yang digunakan dalam penelitian ini adalah metode penelitian kuantitatif. Penelitian Ini dilakukan pada restoran Hayaku, yang melingkupi cabang diberbagai tempat, antara lain di Kota Surabaya, Malang, Batu, dan Jogja. Teknik yang digunakan untuk mengambil sampel dari total populasi karyawan yang bekerja di Hayaku adalah dengan mengambil seluruh populasi untuk dijadikan sampel yaitu berjumlah 50 sampel. Metode pengumpulan data yang digunakan adalah dengan metode angket atau kuesioner. Dengan metode analisis jalur (Path Analysis) pada software SPSS 16.0.

HASIL DAN PEMBAHASAN

Tabel 1. Frekuensi Jawaban Responden Terhadap Kepemimpinan Transformasional (X)

\begin{tabular}{|c|c|c|c|c|c|c|c|c|c|c|c|}
\hline \multirow{2}{*}{ Item } & \multicolumn{2}{|c|}{ STS } & \multicolumn{2}{|c|}{ TS } & \multicolumn{2}{|c|}{$\mathbf{N}$} & \multicolumn{2}{|c|}{$\mathbf{S}$} & \multicolumn{2}{|c|}{ SS } & \multirow{2}{*}{ Mean } \\
\hline & $\mathbf{F}$ & $\%$ & $\mathbf{F}$ & $\%$ & $\mathbf{F}$ & $\%$ & $\mathbf{F}$ & $\%$ & $\mathbf{F}$ & $\%$ & \\
\hline X1.1 & 1 & 2,0 & 2 & 4,0 & 16 & 32,0 & 21 & 42,0 & 10 & 20,0 & 3,74 \\
\hline $\mathrm{X} 1.2$ & 1 & 2,0 & 1 & 2,0 & 8 & 16,0 & 25 & 50,0 & 15 & 30,0 & 4,04 \\
\hline $\mathrm{X} 1.3$ & - & - & 4 & 8,0 & 9 & 18,0 & 28 & 56,0 & 9 & 18,0 & 3,84 \\
\hline $\mathrm{X} 1.4$ & - & - & 3 & 6,0 & 12 & 24,0 & 24 & 48,0 & 11 & 22,0 & 3,86 \\
\hline $\mathrm{X} 1.5$ & 1 & 2,0 & 2 & 4,0 & 8 & 16,0 & 26 & 52,0 & 13 & 26,0 & 3,96 \\
\hline X1.6 & - & - & 3 & 6,0 & 11 & 22,0 & 22 & 44,0 & 14 & 28,0 & 3,94 \\
\hline X1.7 & & & 3 & 6,0 & 4 & 8,0 & 26 & 52,0 & 17 & 34,0 & 4,14 \\
\hline & & & & & & tal & & & & & 3,93 \\
\hline
\end{tabular}

Output total rata-rata skor untuk variabel kepemimpinan transformasional (X) sebesar 3,93. Nilai 3,93 memiliki nilai interval dalam 3,41- 4,20 sehingga bisa disimpulkan bahwa distribusi frekuensi jawaban responden kepemimpinan transformasional adalah baik.

Tabel 2.Frekuensi Jawaban Responden Terhadap Kinerja Karyawan (Y)

\begin{tabular}{|c|c|c|c|c|c|c|c|c|c|c|c|}
\hline \multirow{2}{*}{ Item } & \multicolumn{2}{|c|}{ STS } & \multicolumn{2}{|c|}{ TS } & \multicolumn{2}{|c|}{$\mathbf{N}$} & \multicolumn{2}{|c|}{$\mathbf{S}$} & \multicolumn{2}{|c|}{ SS } & \multirow{2}{*}{ Mean } \\
\hline & $\mathbf{F}$ & $\%$ & $\mathbf{F}$ & $\%$ & $\mathbf{F}$ & $\%$ & $\mathbf{F}$ & $\%$ & $\mathbf{F}$ & $\%$ & \\
\hline Y1.1 & - & - & - & - & 5 & 10,0 & 29 & 58,0 & 16 & 32,0 & 4,22 \\
\hline Y1.2 & - & - & - & - & 9 & 18,0 & 31 & 62,0 & 10 & 20,0 & 4,02 \\
\hline Y1.3 & - & - & - & - & 8 & 16,0 & 30 & 60,0 & 12 & 24,0 & 4,08 \\
\hline Y1.4 & - & - & - & - & 14 & 28,0 & 21 & 42,0 & 15 & 30,0 & 4,02 \\
\hline Y1.5 & - & - & 2 & 4,0 & 11 & 22,0 & 22 & 44,0 & 15 & 30,0 & 4,00 \\
\hline Y1.6 & - & - & - & - & 10 & 20,0 & 28 & 56,0 & 12 & 24,0 & 4,04 \\
\hline
\end{tabular}




\begin{tabular}{|c|c|c|c|c|c|c|c|c|c|c|c|}
\hline Y1.7 & - & - & 1 & 2,0 & 7 & 14,0 & 28 & 56,0 & 14 & 28,0 & 4,10 \\
\hline \multicolumn{10}{|c|}{ Rata-rata Total } \\
\hline
\end{tabular}

Output total rata-rata skor untuk variabel kinerja karyawan (Y) sebesar 4,06. Nilai 4,06 memiliki nilai interval dalam 3,41-4,20 sehingga bisa disimpulkan bahwa distribusi frekuensi jawaban responden kinerja karyawan adalah baik.

Tabel 3. Frekuensi Jawaban Responden Terhadap Motivasi (Z)

\begin{tabular}{|c|c|c|c|c|c|c|c|c|c|c|c|}
\hline \multirow{2}{*}{ Item } & \multicolumn{2}{|c|}{ STS } & \multicolumn{2}{c|}{ TS } & \multicolumn{2}{|c|}{ N } & \multicolumn{2}{|c|}{ S } & \multicolumn{2}{|c|}{ SS } & \multirow{2}{*}{ Mean } \\
\cline { 2 - 12 } & F & \% & F & \% & F & \% & F & \% & F & \% & \\
\hline Z1.1 & - & - & 4 & 8,0 & 13 & 26,0 & 28 & 56,0 & 5 & 10,0 & 3,68 \\
\hline Z1.2 & - & - & 1 & 2,0 & 10 & 20,0 & 28 & 56,0 & 11 & 22,0 & 3,98 \\
\hline Z1.3 & - & - & - & - & 16 & 32,0 & 22 & 44,0 & 12 & 24,0 & 3,92 \\
\hline Z1.4 & 2 & 4,0 & 5 & 10,0 & 14 & 28,0 & 19 & 38,0 & 10 & 20,0 & 3,60 \\
\hline Z1.5 & - & - & 2 & 4,0 & 11 & 22,0 & 21 & 42,0 & 16 & 32,0 & 4,02 \\
\hline Z1.6 & - & - & 1 & 2,0 & 9 & 18,0 & 23 & 46,0 & 17 & 34,0 & 4,12 \\
\hline Z1.7 & - & - & 4 & 8,0 & 10 & 20,0 & 24 & 48,0 & 12 & 24,0 & 3,88 \\
\hline Z1.8 & - & - & 1 & 2,0 & 12 & 24,0 & 27 & 54,0 & 10 & 20,0 & 3,92 \\
\hline Z1.9 & 1 & 2,0 & - & - & 11 & 22,0 & 27 & 54,0 & 11 & 22,0 & 3,94 \\
\hline \multicolumn{8}{|c|}{ Rata-rata Total } \\
\hline
\end{tabular}

Output total rata-rata skor untuk variabel Motivasi (Z) sebesar 3,89. Nilai 3,89 memiliki nilai interval dalam 3,41-4,20 sehingga bisa disimpulkan bahwa distribusi frekuensi jawaban responden terhadap motivasi adalah baik.

\section{Uji Hipotesis}

Tabel 4. Pengaruh Kepemimpinan Transformasional (X) Terhadap Kinerja (Y)

\begin{tabular}{|c|c|c|c|c|}
\hline Model & Standartdized Coefficients & $\mathbf{T}$ & Sig. & Keterangan \\
\hline $\mathrm{X}$ & 0,489 & 3,884 & 0,000 & Signifikan \\
\hline \multicolumn{5}{|c|}{ Dependent Variabel: Y } \\
\hline
\end{tabular}

Sumber: Data diolah peneliti: 2019

Berdasarkantabel4, kepemimpinan transformasional memiliki nilai signifikansi 0,000 yang berarti di bawah 0,05 serta memiliki nilai koefisien positif yaitu 0,489 terhadap kinerja karyawan. Hal tersebut dapat disimpulkan bahwa kepemimpinan transformasional memiliki hubungan yang positif dan signifikan terhadap kinerja.

Tabel 5. Pengaruh Motivasi (Z) Terhadap Kinerja (Y)

\begin{tabular}{|c|c|c|c|c|}
\hline \multirow{2}{*}{ Model } & $\begin{array}{c}\text { Standartdized } \\
\text { Coefficients }\end{array}$ & \multirow{2}{*}{ T } & Sig. & Keterangan \\
\cline { 2 - 4 } & Beta & 5,726 & 0,000 & Signifikan \\
\hline $\mathrm{Z}$ & 0,637 & \multicolumn{4}{c|}{ Dependent Variabel: Y } \\
\hline
\end{tabular}

Sumber: Data diolah peneliti: 2019

Berdasarkan table 5, motivasi memiliki nilai signifikansi 0,000 yang berarti di bawah 0,05 serta memiliki nilai koefisien positif yaitu 0,637 terhadap kinerja. Hal tersebut dapat disimpulkan bahwa motivasi memiliki hubungan yang positif dan signifikan terhadap kinerja. 
Tabel 6. Pengaruh Kepemimpinan Transformasional (X) Terhadap Motivasi (Z)

\begin{tabular}{|c|c|c|c|c|}
\hline \multirow{2}{*}{ Model } & Standartdized Coefficients & \multirow{2}{*}{ T } & \multirow{2}{*}{ Sig. } & Keterangan \\
\cline { 2 - 5 } & Beta & 7,244 & 0,000 & Signifikan \\
\hline \multicolumn{4}{|c|}{ Xependent Variabel: Z } \\
\hline
\end{tabular}

Sumber: Data diolah Peneliti: 2019

Berdasarkantabel 6, Kepemimpinan Transformasional Memiliki nilai signifikansi 0,000 terhadap motivasi, yang berarti dibawah 0,05 serta memiliki nilai koefisien positif yaitu 0,723 . Hal tersebut dapat disimpulkan bahwa kepemimpinan transformasional memiliki hubungan yang positif dan signifikan terhadap motivasi.

Tabel 7. Pengaruh Kepemimpinan Transformasional (X) Dan Motivasi (Z) Terhadap Kinerja (Y)

\begin{tabular}{|c|c|c|c|}
\hline Model & F & Sig. & Keterangan \\
\hline $\mathrm{X}$ dan Z & 16,167 & 0,000 & Signifikan \\
\hline \multicolumn{4}{|c|}{ Dependent Variabel: Y } \\
\hline
\end{tabular}

Sumber: Data diolah peneliti: 2019

Berdasarkan tabel 7, kepemimpinan transformasional dan motivasi memiliki nilai signifikansi 0,000 terhadap kinerja, yang berarti dibawah 0,05 serta memiliki nilai $\mathrm{F}$ hitung yaitu 16,167 yang berarti diatas $\mathrm{F}$ tabel yaitu 3,20. Hal tersebut dapat disimpulkan bahwa kepemimpinan transformasional dan motivasi secara simultan (bersama-sama) mempengaruhi kinerja.

Tabel 8. Pengaruh Langsung dan Tidak Langsung

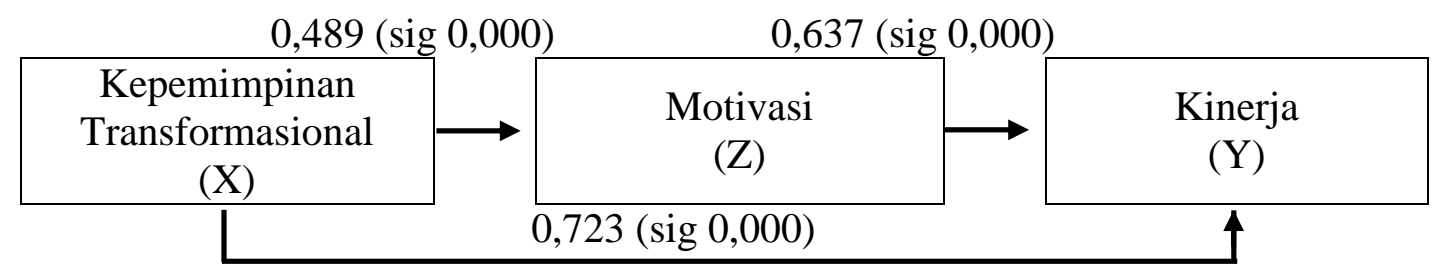

Sumber: Data diolah peneliti: 2019

Hasil analisis jalur dengan menggunakan SPSS menunjukkan bahwa ada pengaruh secara langsung variabel kepemimpinan transformasional terhadap kinerja karyawan yaitu 0,723 . Dan untuk besarnya pengaruh total $0,489+0,637=1,135$.

\section{Pembahasan Penelitian}

\section{Pengaruh Kepemimpinan Transformasional terhadap Kinerja}

Kepemimpinan transformasional terhadap kinerja karyawan memiliki nilai signifikansi 0,000 yang berarti dibawah 0,05 serta memiliki nilai koefisien positif yaitu 0,489. Hal tersebut dapat disimpulkan bahwa kepemimpinan transformasional memiliki hubungan yang positif dan signifikan terhadap kinerja.

Hasil analisis tersebut menunjukan bahwasanya gaya kepemimpinan transformasional memiliki pengaruh positif terhadap kinerja karyawan, dalam segi cara atau sikap dari pemimpin terhadap karyawan. Kartono (2002), menjelaskan bahwa "gaya kepemimpinan adalah cara bekerja dan bertingkah laku pemimpin dalam 
membimbing para bawahannya untuk berbuat sesuatu".Kepemimpinan transformasional dapat diterapkan dalam gaya kepemimpinan Hayaku, sesuai dengan penelitian ini, kepemimpinan transformasional melingkupi karakteristiknya merupakan gaya kepemimpinan yang baik dalam memberikan arahan dan dampak positif bagi kinerja karyawan Hayaku.

\section{Pengaruh Motivasi terhadap Kinerja}

Motivasi terhadap kinerja memiliki nilai signifikansi 0,000 yang berarti dibawah 0,05 serta memiliki nilai koefisien positif yaitu 0,637. Hal tersebut dapat disimpulkan bahwa motivasi terhadap kinerja memiliki hubungan yang positif dan signifikan.

Hasil penelitian ini menunjukan betapa pentingnya motivasi bagi kinerja kayawan Hayaku. Hal tersebut dibuktikan dengan hasil data penelitian yang membuktikan motivasi berpengaruh positif dan signifikan terhadap kinerja karyawan Hayaku. Selaras dengan yang di kemukakan Gomez dalam Zulkifli (2013), mengemukakan bahwa motivasi itu merupakan sebuah perilaku yang mengandung dorongan kepada seseorang untuk bersedia bekerja sama secara maksimal guna tercapainya tujuan bersama serta tujuanperusahaan. Dari hal tersebut, perlu adanya motivasi guna mempertahankan ataupun meningkatkan kinerja seseorang karyawan.

\section{Pengaruh Kepemimpinan Transformasional terhadap Motivasi}

Kepemimpinan transformasional terhadap motivasi memiliki nilai signifikansi 0,000 yang berarti dibawah 0,05 serta memiliki nilai koefisien positif yaitu 0,723 . Hal tersebut dapat disimpulkan bahwa kepemimpinan transformasional terhadap motivasi memiliki hubungan yang positif dan signifikan.

Hasil penelitian ini menujukan hubungan yang signifikan antara kepemimpinan transformasional terhadap motivasi bagi karyawan Hayaku. Dari hal tersebut, manajemen Hayaku tentunya dapat menggunakan sikap dari kepemimpinan transformasional guna memberikan atau meninkatkan motivasi terhadap karyawan. Penjelan tersebut didukung oleh sebuah bukti empiris yang telah dilakukan oleh salah seorang peneliti, Rizqiah (2013) yang telah menyatakan dalam penelitianya dengan uji empiris bahwasanya gaya kepemimpinan transformasional perpengaruh positif terhadap motivasi kerja.

\section{Pengaruh Kepemimpinan Transformasional dan Motivasi terhadap Kinerja}

Kepemimpinan transformasioanal dan motivasi terhadap kinerja memiliki nilai signifikansi 0,000 yang berarti dibawah 0,05 serta memiliki nilai $F$ hitung yaitu 16,167 yang berarti diatas $\mathrm{F}$ tabel yaitu 3,20. Hal tersebut dapat disimpulkan bahwa kepemimpinan transformasional dan motivasi secara simultan (bersama-sama) mempengaruhi kinerja.

Hasil penelitian ini menunjukan bahwa kepemimpinan transformasional berpengaruh positif terhadap kinerja karyawan melalui variabel motivasi. Kepemimpinan transformasional memungkinkan dapat memberikan dampak positif terhadap motivasi pada karyawan Hayaku kemudian mampu memberikan peningkatan kinerja kepada keryawan Hayaku.

Selaras dengan penelitian yang telah dilakukan oleh Dwanggi (2017), dalam penelitianya yang berjudul Pengaruh Kepemimpinan Transformasional dan Budaya Organisasi Terhadap Kinerja Pada Guru Dengan Motivasi Sebagai Variabel Intervening. Menyatakan bahwa motivasi memiliki peranan dalammemediasi pengaruh kepemimpinan transformasional pada kinerja. Dalam penelitian ini mengungkapkan bahwa kepemimpinan transformasional dapat mendorong motivasi guru untuk bekerja 
lebih baik dan sesuai dengan arahan pimpinannya. Sehingga kinerja guru pun akan semakin meningkat. Dari hasil penelitian tersebut dapat di ketahui bahwasanya terdapat hubungan yang positif dari kepemimpinan transfomasional terhadap kinerja melalui motivasi kerja.

\section{KESIMPULAN DAN SARAN Kesimpulan}

1. Kepemimpinan transformasional berpengaruh terhadap kinerja karyawan. Kepemimpinan transformasional mampu memberikan dampak positif bagi kinerja karyawan, semakin baik kepemimpinan transformasional di lakukan maka kinerja karyawan akan semakin baik, sehingga nantinya karyawan dapat memberikan kinerja yang baik pula bagi perusahaan. Hal ini dibuktikan dengan nilai signifikansi 0,000 yang berarti dibawah 0,05 serta memiliki nilai koefisien positif yaitu 0,489.

2. Motivasi berpengaruh positif terhadap kinerja karyawan. Artinya, semakin tinggi motivasi yang diberikan terhadap karyawan, maka dapat meningkatkan performa kinerja. Hal ini dibuktikan dengan nilaisignifikansi 0,000 yang berartidibawah 0,05 sertamemilikinilaikoefisienpositifyaitu 0,637.

3. Kepemimpinan transformasional berpengaruh positif terhadap motivasi. Artinya, kepemimpinan transformasional yang dilakukan dengan baik di dalam operasional perusahaan, maka akan memberikan motivasi yang baik juga bagi karyawan. Hal ini dibuktikan dengan nilaisignifikansi 0,000 yang berarti dibawah 0,05 serta memiliki nilai koefisien positif yaitu 0,723 .

4. Kepemimpinan transformasional berpengaruh positif terhadap kinerja karyawan dengan motivasi sebagai variabel intervening. Artinya, motivasi dapat menjadi variabel mediasi yang baik antara kepemimpinan transformasional terhadap kinerja karyawan. Hal ini dibuktikan dengan nilai signifikansi 0,000 yang berarti dibawah 0,05 serta memiliki nilai $\mathrm{F}$ hitung yaitu 16,167 yang berarti diatas $\mathrm{F}$ tabel yaitu 3,20.

\section{Saran}

1. Bagi pihak perusahaan

Perlu adanya peningkatan terhadap pemahaman karyawan terkait pedoman pelaksanaan tugas (SOP) yang ada diperusahaan, memberikan pendekatan sosial yang baik terhadap karyawan,serta memperhatikan keamanan dalam operasional pekerjaan karyawan salah satunya dengan memberikan jaminan kesehatan bagi karyawan.

2. Bagi akademisi

Hasil penelitian ini dapat dijadikan rujukan untuk penelitian selanjutnya, khususnya terkait pengaruh kepemimpinan transformasional terhadap kinerja karyawan dengan motivasi sebagi variabel intervening. Penelitian ini masih banyak kesalahan maupun kekurangan, sehingga harapanya bisa lebih baik bagi peneliti yang selanjutnya.

\section{DAFTAR PUSTAKA}

Anoraga Pandji, (2009). Manajemen bisnis, jakarta: rineka cipta, Psikologi kepemimpinan. Jakarta:rineka cipta.

Dewanggi Aurelia H.P (2017). "Pengaruh Kepemimpinan Transformasional dan Budaya 
Organisasi Terhadap Kinerja Pada Guru Dengan Motivasi Sebagai Variabel Intervening".jurnal.uns.ac.id.

Emilia Ika Andriani. (2016) SKRIPSI. Judul: "Pengaruh Gaya Kepemimpinan Terhadap Kinerja Karyawa pada Rumah Sakit Panti Indah Yogyakarta".Hasibuan. (2005) Manajemen Sumber Daya Manusia, Edisi Revisi, Jakarta: Bumi Aksara.

Juvenalis Mwombeki (2017) Jurnal. Judul: Influence Of Leadership Styles on Employees' Performance In Tanzania (The Case Of University Of DSM Computing Centre).

Kartono, Kartini. (2002) Pemimpin dan kepemimpinan. Jakarta: Rajawali Press.

Kiptiyah (2015) "Pengaruh Gaya Kepemimpinan Transformasional Dan Kompensasi Terhadap Kinerja Karyawan”. Eprints.uny.ac.id. Skripsi.

Mansyur Ramli, S.E., M. Si, dkk. (2014). Manajemen Sumber Daya manusia Untuk Perusahaan, cet 06, Jakarta: Rajawali Pers

Rizqiah (2013) Jurnal. "Analisis Pengaruh Gaya Kepemimpinan dan Disiplin Kerja Terhadap Kinerja Pegawai dengan Motivasi sebagai Variabel Intervening”. Ejurnal3.undip.ac.id.

Septiyan Bayu (2017). Jurnal. administrasibisnis.studentjournal.ub.ac.id.

Zulkfli Muhammad .(2013). SKRIPSI. Pengaruh Gaya Kepemimpinan, Motivasi, Disiplin Kerja, Kompetensi dan Budaya Organisasi terhadap Kinerja Karyawan (Studi Kasus Pada Direktorat Budidaya dan Pascapanen Florikultura Pasar Minggu Jakarta

Selatan. Anoraga pandji, (2009). Manajemen bisnis, jakarta: rineka cipta, Psikologi kepemimpinan. Jakarta:rineka cipta.

Armstrong, Michael, (1990). Manajemen Sumber Daya Manusia, terjemahan Sofyan dan Haryanto, Jakarta: PT. Elex Media Komputindo.

Azwar. S (2007). Metode Penelitian, Yogyakarta: Pustaka Belajar (2015). Realiabilitas dan validitas. Yogyakarta: Pustaka Belajar

Benardin, H. John and Joyce E. A. Russell. (1998). Human Resources Management: An Expriential Approach. Series In Management. New York : McGraw.

Dariyo, A. (2006). Psikologi Perkembangan Anak Tiga Tahun. Jakarta: PT Refika Aditama.

Desianty, Sovyia. (2005)."Pengaruh Gaya Kepemimpinan Terhadap Komitmen Organisasi Pada PT.Pos Indonesia (Persero) Semarang”.Jurnal Studi Manajemen dan Organisasi,Vol 2,No 1.

Dewanggi Aurelia H.P (2017). "Pengaruh Kepemimpinan Transformasional dan Budaya Organisasi Terhadap Kinerja Pada Guru Dengan Motivasi Sebagai Variabel Intervening”. jurnal.uns.ac.id.

Eko Nugroho, (2011) Jurnal. Pengaruh Coaching Terhadap Motivasi Kerja dan Kinerja Individual (Studi Kasus pada Karyawan Bagian Support Services Departemen Production Services PT. International Nikel Indonesia, Tbk).

Emilia Ika Andriani. (2016) SKRIPSI. Judul: "Pengaruh Gaya Kepemimpinan Terhadap Kinerja Karyawa pada Rumah Sakit Panti Indah Yogyakarta".

Gordon, Thomas. (1977), Menjadi Pemimpin Efektif, cet.3, Jakarta: PT Gramedia Pustaka Utama.

Hasibuan. (2005) Manajemen Sumber Daya Manusia, Edisi Revisi, Jakarta: Bumi Aksara.

Heidjrachan \& husnan. (2002), Manajemen Personalia, Yogyakarta: BPFE UGM. 
Irham fahmi. (2016). Pengantar Manajemen Sumber Daya Manusia, Jakarta Mitra Wacana Media.

Juvenalis Mwombeki (2017) Jurnal. Judul: Influence Of Leadership Styles on Employees' Performance In Tanzania (The Case Of University Of DSM Computing Centre)

Jajang A. (2014) Judul: "Pengaruh Gaya Kepemimpinan Terhadap Kinerja Karyawan (Studi pada Perusahaan Tegel Malang Indah Genteng Rajawali)". SKRIPSI.

Johni damyati. M. (2013). Metodologi Penelitian Pendidikan dan Aplikasinya Pada PAUD, Jakarta: Kencana.

Kartono, Kartini. (2002) Pemimpin dan kepemimpinan. Jakarta: Rajawali Press.

Kiptiyah (2015) SKRIPSI. "Pengaruh Gaya Kepemimpinan Transformasional Dan Kompensasi Terhadap Kinerja Karyawan”. Eprints.uny.ac.id.

Mathis, Robert L. Dan John H. Jackson. (2001). Manajemen Sumber Daya Manusia. Jakarta: Salemba Empat.

Mansyur Ramli, S.E., M. Si, dkk. (2014). Manajemen Sumber Daya manusia Untuk Perusahaan, cet 06, jakarta: rajawali pers.

Muhammad Zulkifli. (2013). Pengaruh Gaya Kepemimpinan, Motivasi, Disiplin Kerja,Kompetensi dan budaya organisasi Terhadap Kinerja Pegawai, (Studi Kasus Pada Direktorat Budidaya dan Pascapanen Florikultura Pasar Minggu Jakarta Selatan, SKRIPSI.

Noor.J, (2017). Metodologi Penelitian: Skripsi, Tesis, Disertasi, dan Karya Ilmiah. Jakarta. PT Fajar Interpratama Mandiri.

Prasetyo, Lis. (2008). " Pengaruh Gaya Kepemimpinan Terhadap Kinerja”,Jurnal Neo Bisnis, Vol 2,No.2.

Prasetyo, (2012). Metode Penelitian Kuantitatif: teori dan aplikasi. jakarta: PT Raja Grafindo Persada.

Purwanto, (2007). Panduan Laboratorium Statistik Inferensia, Jakarta: Grasindo.

Santoso, S. (2010). Statistik Multivariat. Jakarta: PT Elex Media Komputindo.

Supratiknya. (1995). Tinjauan Psikologi Komunikasi Antar Pribadi. Yogyakarta : kanisius. (Anggota IKAPI).

Suryono. (2018). Analisis Regresi untuk Peneitian. Yogyakarta: Deepublish (Group Penerbit CV. Budi Utama).

Septiyan Bayu (2017). Jurnal. administrasibisnis.studentjournal.ub.ac.id.

Rizqiah (2013) Jurnal. "Analisis Pengaruh Gaya Kepemimpinan dan Disiplin Kerja Terhadap Kinerja Pegawai dengan Motivasi sebagai Variabel Intervening”. Ejurnal3.undip.ac.id.

Reza Agam Kurniawan. (2012) Judul: "Pengaruh Motivasi Kerja, Kepemimpinan,dan Budaya Organisasi terhadap Kinerja Karyawan pada PT. BPR Kusuma Danaraja". SKRIPSI.

Rivai, Veithzal. (2004), Kiat Memimpin Dalam Abad Ke-21, Ed.1, Jakarta: PT RajaGrafindo Persada.

Thoha, Miftah. (2010) Perilaku Organisasi: Konsep Dasar dan Aplikasinya.Jakarta: Rajawali Pers.

Veronica dkk. (2017) Impact Of Leadership Style On Employee Performance ( a case study on a private organizational in Malaysia) 